\title{
Performance and Carcass of Super Native Chickenn Provided by Fermented Gamal Leaf in Different Cutting Age
}

\author{
Yan Tonga ${ }^{1}$, Luh Suariani ${ }^{2}$, I Nyoman Kaca Ni Made Yudiastari ${ }^{3}$, \\ Ni Ketut Etty Suwitari ${ }^{4}$ \\ tongayan64@gmail.com ${ }^{1}$
}

\begin{abstract}
Animal Husbandry Department, Agriculture of Faculty, Warmadewa University
Abstract. The purpose of this study was to see the effect of fermented gamal leaves on the appearance of super native chickens and at the optimum cutting age for cutting, and to see the interaction between the administration of fermented gamal leaves and the age of super native chicken. The study was conducted using a completely randomized design method of $4 \times 3$ factorial pattern with 4 treatments of fermented gamal leaves and 3 treatments of cutting age. As for Factor A (level of administration of fermented gamal leaf flour / TGT), namely: R0 (ration without gamal leaf flour fermented), R1 (ration containing 2\% fermented gamal leaves), R2 (ration with 4\% fermented gamal leaves), R3 (Ration with 6\% fermented gamal leaves), while Factor B (cutting age), namely: U1 (cutting age 8 weeks), U2 (cutting age 10 weeks), U3 (cutting age 12 weeks). Each treatment combination was repeated three (3) times, and each replication would consist of 6 super native chickens. The variables observed included: 1). Growth of aged chickens included weight gain and final body weight of super free-range chickens, 2) Percentages of super-carcasses and noncarcasses of superfathers at each cutting age, 3) Feed Convertion Ratio (FCR) of each treatment at 8, 10 and 12 weeks of cutting age, 4) Feed consumption at each treatment is at 8,10 and 12 weeks. The results showed that there were significant $(\mathrm{P}<0,05)$ interactions between levels of fermented gamal administration with cutting age for weight gain and feed consumption variables, while for the final weight and for variables both factors showed a real effect but there was no interaction between the two. For the percentage of carcass, the cutting age has a significant effect $(\mathrm{P}<0.05)$, but gamal administration does not show a significant effect and there is no interaction in both factors $(\mathrm{P}>0.05)$. The conclusion of this study is that the administration of fermented gamal leaves to the level of R1 $(3 \%)$ is significantly able to increase the growth of super native chickens. The right cut can be done after the chicken is 10 weeks old.
\end{abstract}

Keywords: Performance, Carcass, Super Kampung Chicken, Gamal Leaf, Fermentation 


\section{$1 \quad$ Introduction}

Along with the development of the world of tourism in Bali, the development of typical Balinese culinary is increasingly rapid. One of the typical Balinese culinary hunts by domestic and foreign tourists is betutu chicken. Raw material from betutu chicken which is much needed and sold well is free-range chicken. One chicken that can be developed is super chicken. Free-range chicken is a local chicken in Indonesia whose life is closely related to the community, free-range chicken is also known as domestic chicken (not race), or vegetable chicken. The appearance of free-range chickens is very diverse, as is the genetic nature, the spread is very wide because the population of native chickens is found in cities and villages. Its potential should be developed to improve community nutrition and increase family income. Recognized or not the consumer's appetite for free-range chicken is very high. This can be seen from the population growth and demand for native chickens which are increasing from year to year [1].

In the maintenance of chicken livestock, high costs are needed, especially in the supply of rations. The ration is the largest component of production costs which can reach $60-70 \%$ of the total production cost. Meanwhile the provision of quality rations can increase the productivity of super chicken. With the high cost of feed, innovation is needed in compiling rations by utilizing existing resources. Efforts are needed to find alternative feed ingredients by utilizing inexpensive, easy to find non-conventional ration ingredients, good quality and not competing with human food and can reduce production costs. One of the ingredients found is gamal leaf (Glisirida sepium) which is a type of legume plant and has a high nutrient content (crude protein content reaches $25 \%$ ) [2]. The use of legume plants as material for poultry rations requires human assistance. Leaves from this type of plant can be processed into flour so that it can be consumed by poultry. Gamal leaf as an alternative feed material that can be used and selected as a constituent ingredient considering that it is easily available and has good nutritional content and is available continuously. The nutritional content of gamal leaves is crude protein $25.17 \%$, fat $2.9 \%$. Ash $8.8 \%$, crude energy $19.89 \mathrm{kj} / \mathrm{kg} \mathrm{Ca} 2.0 \%, \mathrm{P} 0.35 \%, \mathrm{Na} 0.4 \%$ and $\mathrm{Mg} 0.75 \%$ [32] But gamal also has low reliability because it has a specific odor. This smell comes from coumarin compounds. Therefore it is necessary to try to increase the nutritional content of gamal leaves. In addition to withering, another thing that can be done is to do fermentation. Fermentation is done to facilitate poultry digesting gamal leaves. Fermentation of gamal leaves will increase crude protein and reduce its crude fiber content and will increase the digestibility value. Fermentation will break the bonds of lignin and cellulose into easier-to-digest carbohydrates.

Super native chickens can be harvested from the age of 6 weeks depending on the designation. In Bali the chicken used for ceremonies can usually be used for 6 weeks old chicken. Usually at the age of 2 months maintenance can reach a weight of $0.8 \mathrm{~kg}$. The results of the average body weight of 4-6 month old domestic chickens were obtained in the range of 0.99-1.22 $\mathrm{kg}$ and $1.47-1.78 \mathrm{~kg}$ in roosters. [3] reported that the body weight of domestic chicken at 12 weeks was $0.70 \mathrm{~kg}$ and at the age of 20 weeks. When compared with local chickens in other countries, domestic chicken in every country in the Asian region almost has the same body weight. [4] states that the average body weight of male hens is $2,405,141 \pm 151,510 \mathrm{~g}$ and females $1,650,00 \pm$ $124,31 \mathrm{~g}$. The growth rate of super native chicken can be said to be good, which can reach a weight of $0.6-0.8 \mathrm{~kg}$ at a maintenance age of 45 days, with a high level of feed consumption. 
Based on the description above, a study was conducted to determine the various levels of giving fermented gamal leaves to the growth and carcass of super chicken at the age of 8,10 and 12 weeks.

\section{Formulation of the Problem}

From the above conditions can be formulated a problem:

a. At what level can the administration of fermented gamal leaf flour provide the best growth and carcass?

b. At what age is the optimum cut for sale?

\section{$3 \quad$ Research Purposes}

The purpose of this study was to determine the optimum level of leaf administration of gamal and at what age was the optimum for cutting / selling.

\section{$4 \quad$ Urgency of Research}

Culinary business in Bali is growing along with the increasing world of tourism. One of the special and rapidly growing culinary in Bali is betutu chicken. The basic ingredients of betutu chicken are native chickens. Native chicken farming is a business that has good prospects to be applied in the community. This business is relatively quick to produce because native chickens can already be sold at the age of 55-70 days. Meanwhile in carrying out the effort of raising chickens the cost of ration was a very large cost which could reach $60 \%$. Therefore, it is deemed necessary to use alternative feed ingredients that can be used as feed ingredients that have good nutritional value. Chicken in its maintenance is usually given forages or other feed ingredients in its maintenance. Gamal leaf is one of the leaves of legume which can be used as feed for native chickens. This is because gamal leaves are easily available, do not compete with human needs and have high nutritional content. Behind excellence with its nutritional content, gamal also has a disadvantage of containing poison coumarin and also has a high tannin content. One way to reduce toxicity and high tannin levels is by fermentation. Before fermentation the leaves of gamal will be dried and then pressed. This is done so that gamal leaf flour can be stored for a long time.

In the daily life the harvest age of native chickens differs according to their designation. In Bali, the designation of chickens for ceremonies requires a smaller size than for consumption. For consumption purposes, chickens with a weight ranging from $0.8-1.0 \mathrm{~kg}$ are usually needed. From these conditions, it is deemed necessary to know the growth, consumption of rations and carcasses of native chickens at various cutting ages. 


\section{$5 \quad$ Methodology}

\section{a. Location and Duration of Research}

This research will be divided into 2 activities, namely: 1) Preparing alternative feed ingredients, namely gamal leaf flour, 2) Research on super chicken raising which will be carried out at the Basic Science Laboratory of the Faculty of Agriculture, Warmadewa University for 3 (three) months.

\section{b. Research Methods}

The study was carried out using a completely randomized design model of $4 \times 3$ factorial pattern with 4 treatments of fermented gamal leaves (Factor A) and 3 treatments of cutting age (Factor B). The Factor A (Level of Giving Fermented Gamal Flour) is:

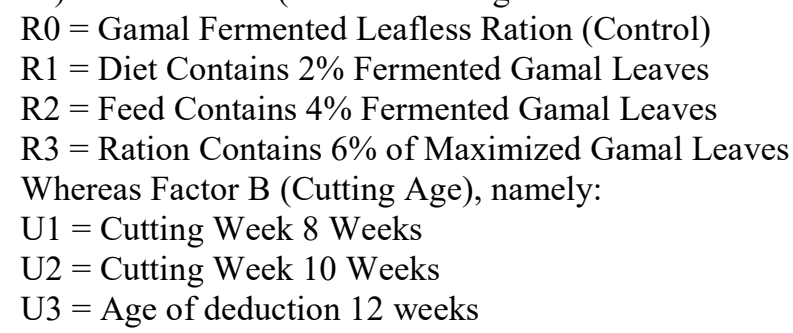

So that the combination of treatments is obtained respectively: RUU1, RUU2, RU3, R1U1, R1U2, R1U3, R2U1, R2U2, R2U3, R3U1, R3U2 and R3U3. Each combination of treatments is repeated three (3) times, and each replication will consist of 6 super native chicken.

\section{c. Ration Used}

In this study used rations consisting of corn, fish meal, rice bran, soybean meal, gamal leaves, coconut oil and minerals. The diet is composed of iso-calorie and iso protein to see the effect of the gamal leaves.

Table 1. Composition of ingredients for the composition of rations of super-village chickens and their respective nutritional content of rations

\begin{tabular}{lllll}
\hline Feed material Used & $\mathrm{R}_{0}$ & $\mathrm{R}_{1}$ & $\mathrm{R}_{2}$ & $\mathrm{R}_{3}$ \\
\hline Corn $(\mathrm{kg})$ & 56 & 58 & 58 & 59 \\
Fermented Gamal Leaf Flour $(\mathrm{kg})$ & 0 & 2 & 4 & 6 \\
Rice brand $(\mathrm{kg})$ & 23 & 19 & 17.5 & 15 \\
Fesh Mill $(\mathrm{kg})$ & 9 & 7 & 5 & 3 \\
Soybean Meal $(\mathrm{kg})$ & 10 & 12 & 13 & 14 \\
Coconut Oil $(\mathrm{kg})$ & 1 & 1 & 1.5 & 2 \\
Mineral $(\mathrm{kg})$ & 1 & 1 & 1 & 1 \\
\hline Amount of & 100 & 100 & 100 & 100 \\
\hline Nutrient Content & $\mathrm{R}_{0}$ & $\mathrm{R}_{1}$ & $\mathrm{R}_{2}$ & $\mathrm{R}_{3}$ \\
\hline Crude Protein $(\%)$ & 17.08 & 17.29 & 17.19 & 17.04
\end{tabular}




\section{d. Chicken Used}

In this study 144 super male chickens were used. DOC super chicken is bought at Tohpati Poultry Shop as many as 300 DOC. From the age of 0 - 3 weeks the chickens are fed with BR I and kept in a postal cage equipped with warmers. After the chickens are 4 weeks old, the chickens are transferred to the battery cage and fed with the treatment ration.

\section{e. Research Steps}

The research begins with preparing gamal leaf flour, drying the gamal dress, grinding it and doing fermentation. After the material is ready, research is done in the field. Newly purchased chickens (DOC) are maintained in a postal cage for 2 weeks equipped with heating devices, drinking places and feed containers. After 4 weeks, new chickens are transferred to the battery cages for each treatment. Every week weighing is carried out. Preparation of rations is carried out every week and weighing the rest of the research is also done every week. Vaccination is carried out according to the schedule of 4 days for ND, 12 days for Gumboro and 21 days for ND. Chicken slaughter is carried out according to the treatment, namely cutting at the age of 8 weeks, 10 weeks and 12 weeks. Feed is given according to treatment in ad libitum. The drinking water provided is sourced from wellbore water at the research site.

\section{f. Variables Observed}

In this study the observed variables were:

1. Age of chicken growth includes Weight Gain and Final Weight of super chicken.

2. Percentage of super chicken carcass at each cutting age

3. Feed Convertion Ratio (FCR) for each treatment at 8,10 and 12 weeks of cutting age.

4. Feed consumption in each treatment, namely at the age of 8,10 and 12 weeks.

\section{g. Data Analysis}

The data obtained were analyzed by variance analysis. If there is a significant difference, it is followed by the Smallest Real Distance Test from Duncan [5]

\section{$6 \quad$ Result and Discussion}

The significance of the research on the appearance and carcass of super native chicken given rations containing fermented gamal leaves is presented in Table 2. The interaction between the levels of fermented gamal leaves and the age of cut was apparent $(\mathrm{P}<0.05)$ in weight gain and ration consumption. While the sole effect of the level of fermented gamal leaf flour was significant $(\mathrm{P}<0.05)$ in the final body weight, feed convention ratio. 


\section{a. Final Weight}

The level factor of fermented gamal leaves and cutting age showed a very significant effect on the final body weight of super native chickens. The administration of fermented gamal leaf flour up to $3 \%$ (R1) was able to increase the final body weight of super native chickens compared to without the provision of fermented gamal leaves (R0), while the provision of fermented gamal leaf flour at higher levels gave lower results than the treatment of R1. This is because the leaves of gamal contain compounds called Coumarin. [6] states that, in gamal leaves there are alkaloid molecules (which cannot be identified) and tanin, a protein binding compound that is classified as an anti-nutrient. Furthermore, it was explained that the weakness of gamal as an ingredient in livestock rations contained toxic substances (anti-nutrients).

Table 2. Significance of Research Results of Raised Chicken Breast Performance and Carcass Contained with Fermented Gamal Leaves

\begin{tabular}{llll}
\hline Change & Fermented Gamal (R) & Cutting Age (U) & Interaction (R X U) \\
\hline Weight Gain & $* *$ & $* *$ & $*$ \\
Final Weiht & $* *$ & $* *$ & $\mathrm{~ns}$ \\
Ration Comsumtion & $* *$ & $* *$ & $*$ \\
Feed Convention Ratio & $* *$ & $* *$ & $\mathrm{~ns}$ \\
(FCR) & & $* *$ & $\mathrm{~ns}$ \\
Precentace of Carcas & ns & $* *$ & . \\
\hline
\end{tabular}

Table 3. Effect offermantated Gamal Leaves on Final Body Weight, Feed Conversion, and Percentage of Super Chicken Chicken Carcass

\begin{tabular}{lllll}
\hline \multirow{2}{*}{ Variable } & \multicolumn{4}{l}{ Variation of Giving Fermented Gamal Leaf Flour } \\
\cline { 2 - 5 } & $\mathrm{R}_{0}$ & $\mathrm{R}_{1}$ & $\mathrm{R}_{2}$ & $\mathrm{R}_{3}$ \\
\hline Final Weight $(\mathrm{g})$ & $629,75^{\mathrm{ab}}$ & $660,32^{\mathrm{a}}$ & $609,32^{\mathrm{ab}}$ & $569,71^{\mathrm{b}}$ \\
FCR & $4,96^{\mathrm{ab}}$ & $4,30^{\mathrm{b}}$ & $5,06^{\mathrm{ab}}$ & $5,29^{\mathrm{a}}$ \\
Carcass Presentase (\%) & $61,0^{\mathrm{a}}$ & $61,3^{\mathrm{a}}$ & $61,0^{\mathrm{a}}$ & $59,0^{\mathrm{a}}$ \\
\hline
\end{tabular}

Note: Numbers followed by different superscript letters on the same line show significant differences $(\mathrm{P}<0.05)$ to very significant $(\mathrm{P}<0.01)$

Table 4. Effect of Age Cutting on Final Body Weight, Ration Conversion and Percentage of Super Village Chicken Carcass

\begin{tabular}{llll}
\hline \multirow{2}{*}{ Variable } & \multicolumn{3}{c}{ Variation of Cutting Age Treatment } \\
\cline { 2 - 4 } & $\mathrm{U}_{1}$ & $\mathrm{U}_{2}$ & $\mathrm{U}_{3}$ \\
\hline Final Body Weight $(\mathrm{g})$ & $482,83^{\mathrm{c}}$ & $572,96^{\mathrm{b}}$ & $796,04^{\mathrm{a}}$ \\
FCR & $3,93^{\mathrm{b}}$ & $5,21^{\mathrm{a}}$ & $5,57^{\mathrm{a}}$ \\
Percentage (\%) & $59,4^{\mathrm{b}}$ & $62,8^{\mathrm{a}}$ & $59,5^{\mathrm{ab}}$ \\
\hline
\end{tabular}

Note: Numbers followed by different superscript letters on the same line show significant differences $(\mathrm{P}<0.05)$ to very significant $(\mathrm{P}<0.01)$ 
At the 3\% level of fermented gamal leaf flour, chickens are still tolerant of the tannin content of gamal leaves. But at the next level (R2 and R3) there is a decrease in final body weight, this is due to the negative effects of tannins found in fermented gamal leaf flour. This is in accordance with the opinion of [7] that in rations containing high tannin reduced nitrogen retention, protein use and digestibility in broiler.

Chicken feed needs should be adjusted to each stage of development of native chickens and their production goals. The higher the age of cutting the higher the weight of native chickens. [8] also believes that the feed given to chickens varies in number depending on age, weight, and production goals. For free-range chicken, because it is genetically natural, its feed needs are sufficiently classified based on the age of the chicken. The logic is that the increase in age occurs during the growth of body weight as well as nutritional needs.

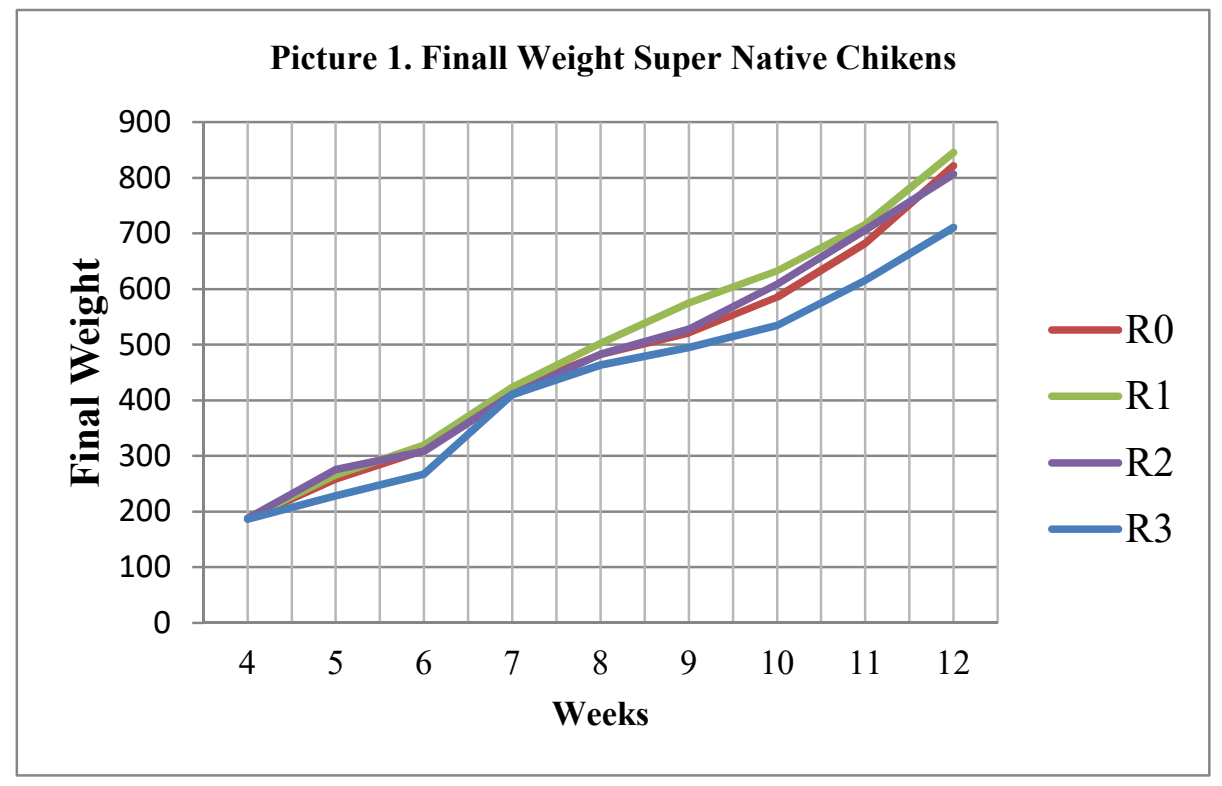

\section{b. Weight Gain}

There was a significant interaction $(\mathrm{P}<0.05)$ between the level of administration of fermented gamal leaf flour and the age of cutting against weight gain of super native chicken. The highest weight gain was obtained at 12 weeks cutting age with $6 \%$ gamal leaf (R2). According to [9] states that the factors that influence weight gain are feed consumption. This opinion is also supported by [10] who states that, in general, weight gain will be influenced by the amount of consumption of food eaten and the nutritional content contained in the feed. [11] explains that growth takes place slowly at first, then quickly and at the last stage slowly returns and then stops altogether. Further explained in several factors that affect chicken growth, among others, nutrition factors that include energy, protein, vitamins, minerals and calcium. 
Table 5. Effects of Interaction Treatment on Super Native Chicken Weight Gain

\begin{tabular}{|c|c|c|c|}
\hline \multirow{2}{*}{ Ration } & \multicolumn{3}{|l|}{ Cutting Age } \\
\hline & $\mathrm{U}_{1}$ & $\mathrm{U}_{2}$ & $\mathrm{U}_{3}$ \\
\hline $\mathrm{R}_{0}$ & $295,45^{\text {fgh }}$ & $295,45^{\mathrm{cd}}$ & $295,45^{\mathrm{a}}$ \\
\hline $\mathrm{R}_{1}$ & $315,60 \mathrm{e}^{\mathrm{fgh}}$ & $315,60^{\mathrm{c}}$ & $315,60^{\mathrm{a}}$ \\
\hline $\mathrm{R}_{2}$ & $294,88^{\mathrm{gh}}$ & $294,88^{\mathrm{b}}$ & $294,88^{\mathrm{a}}$ \\
\hline $\mathrm{R}_{3}$ & $277,34^{\mathrm{h}}$ & $277,34^{\mathrm{def}}$ & $277,34^{\mathrm{b}}$ \\
\hline
\end{tabular}

Note: Numbers followed by different superscript letters on the row and pool show significant differences $(\mathrm{P}<0.05)$ to very significant $(\mathrm{P}<0.01)$

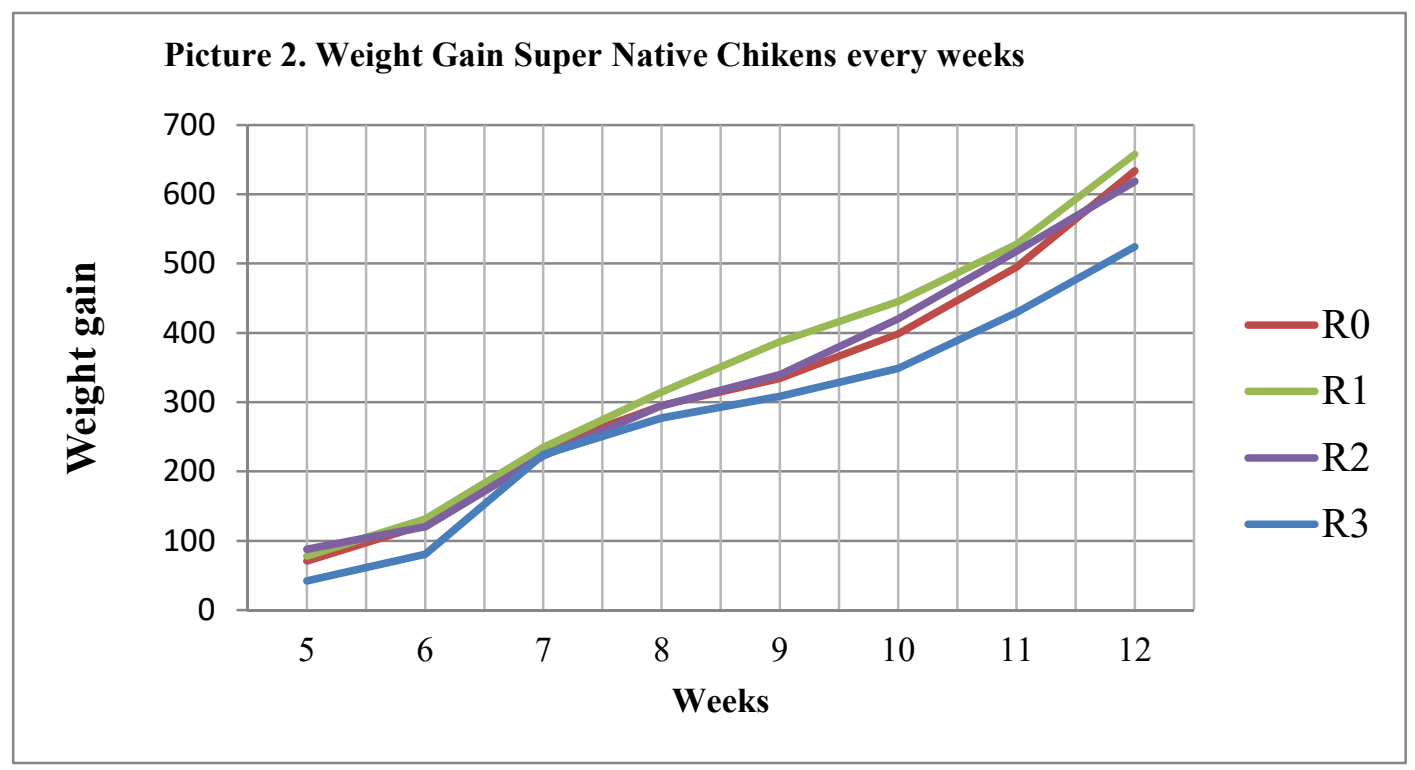

The $0.5-2 \%$ tannin content in poultry feed causes a detrimental effect which is suppressing egg growth and production, whereas at 3-7\% levels can cause death [12]. Based on research conducted by [13] the decrease in consumption occurred in rations containing tannins of $2.71-3.54 \%$. Tanin of $2.76 \%$ causes a decrease in consumption by $19.4 \%$. According to [14], feeding which contains tannins of $0.33 \%$ is not harmful to poultry, especially chickens. If the administration of tannin levels reaches $0.5 \%$ or more causes suppression of chicken growth, because the tannin suppresses nitrogen retention and decreases the digestibility of amino acids which should be absorbed by the intestinal villi which are used for the growth and development of body tissues. Symptoms caused when consuming tannin are slow growth, decreased appetite because of the bitter taste in tannins, abnormal legs (club) and the ability to produce eggs decreases. The negative effects of tannin with levels below 5\% in monogastric animals cause suppression of growth, decrease in protein use, damage to the mucosal wall of the digestive tract, 
reduce excretion of several cations and increase excretion of proteins and some essential amino acids.

\section{c. Ration Consumption}

There is an interaction between the level of administration of fermented gamal leaf flour and the age of cutting to the consumption of chicken ration. The higher the age of cutting, the more the amount of feed consumed, the more the amount of feed consumed means more consumption of fermented gamal leaf flour. Gliricidia sepium or often called gamal has low palatability due to its specific smell [15]. Furthermore, [16] stated that this specific odor originated from the Coumarin compound, so that to overcome this problem it could be done by withering the leaves of gamal before being given to livestock. Before poultry is given, it needs to be processed first. The intended treatment is to change its shape into leaf flour [16]. Another way to increase livestock palatability against gamal leaves is to give it in dry form, because drying can reduce the content of Coumarin and cyanide acid [17] In addition, by using the silage method, gamal leaves can be used as a reserve feed ingredient that is quite durable and preferred by livestock. Tannin is a compound with a high molecular weight containing hydroxyl and several components such as carboxyl which is able to bind complexes with proteins and several other macro minerals in environmental conditions. Tannin has the ability to form complex bonds with protein, starch, cellulose and minerals. Tannin can affect the value of nutrients contained in food and feed consumed by livestock. It is found in legumes, grass and fruit that are not yet ripe. Tannin causes a feeling of shrinking on the tongue, because it is able to bind to salivary fluid in the mouth [12]. According to [18] that tannin is a type of plant content that is phenolic in nature which has a feeling of being tight and has the ability to tan skin. High levels of tannin are considered to have an adverse effect on the nutritional value of animal feed plants. Tannin can poison the liver, because tannin can bind proteins, essential amino acids, and phosphorus minerals, which causes a decrease in feed consumption. [19] states that excessive tannin can suppress chicken growth, tannin suppresses $\mathrm{N}$ retention and causes digestibility of amino acids which can actually be absorbed by intestinal villi and utilized for tissue growth and development.

Table 6. Effect of Treatment Interactions on Super Chicken Chicken Feed Consumption

\begin{tabular}{|c|c|c|c|}
\hline \multirow{2}{*}{ Ration } & \multicolumn{3}{|l|}{ Cutting Age } \\
\hline & $\mathrm{U}_{1}$ & $\mathrm{U}_{2}$ & $\mathrm{U}_{3}$ \\
\hline $\mathrm{R}_{0}$ & $1155,19^{\text {fgh }}$ & $1155,19^{c}$ & $1155,19^{\mathrm{ab}}$ \\
\hline $\mathrm{R}_{1}$ & $1079,34^{\mathrm{h}}$ & $1079,34^{\mathrm{de}}$ & $1079,34^{\mathrm{a}}$ \\
\hline $\mathrm{R}_{2}$ & $1118,08^{\mathrm{gh}}$ & $1118,08^{\text {cde }}$ & $1118,08^{\mathrm{ab}}$ \\
\hline $\mathrm{R}_{3}$ & $1240,05^{\mathrm{fgh}}$ & $1240,05^{\mathrm{e}}$ & $1240,05^{\mathrm{b}}$ \\
\hline
\end{tabular}

Chickens consume rations especially in order to meet their energy needs. Consumption will increase if chickens are given low energy rations [20]. The rate of ration in the digestive tract can affect the amount of ration consumed, the faster the flow of rations in the digestive device, the more the number of rations consumed. Other factors that influence consumption are palatability 
and consumption of rations influenced by ration energy content, ration form, environmental health, nutrients, growth speed, egg production and stress [21] and genetics [20] . In general, consumption increases with increasing body weight of chickens, because chickens with large body weight have the ability to accommodate more food. This is in accordance with the opinion of [22] that feed consumption is influenced by the palatability of feed. According to [22] chickens consume rations to meet their energy needs, before their energy needs are met chicken will continue to eat. If the chicken is fed with a low energy content, the chicken will eat more. Similarly, if the energy content of the ration is high, it will reduce the amount of food. The decreased consumption of rations in this study caused a decrease in the growth of the chicken body, because the nutrients absorbed were low so that they could reduce the appearance of chickens. According to [20] the level of ration consumption is largely determined by the palatability of the ration. The high course fibrous ration causes the ration palatability to decrease which is followed by decreased ration consumption. Decreased ration consumption in this study caused a decrease in chicken weight gain, because the nutrients absorbed were low so as to reduce the percentage of carcass.

\section{d. FCR (Feed Convertion Ratio)}

The level of fermented gamal leaf flour and cutting age showed a very significant effect ( $P>0.01$ ) on the conversion of super native chicken rations. Provision of ration up to $3 \%$ (R1) compared with the level of administration of R0, R1 and R2, while at the cutting age of 8 weeks (U1) gave the lowest FCR value. The low FCR on U1 is because at U1 it still has a fast growth rate, while at U2 and U3 the growth rate has slowed down, so that the resulting weight gain decreases. According to [23], the best conversion of rations is worth 1, meaning that to produce 1 $\mathrm{kg}$ of meat, a ration of $1 \mathrm{~kg}$ is needed. The smaller the conversion rate, the more efficient livestock production. The efficiency of rations given by chickens is usually seen from the conversion rate of rations. The higher conversion ration shows the more rations needed to increase body weight per unit weight. The lower the conversion rate the better, because the use of rations is more efficient. By calculating body weight gain, feed consumption and FCR, chicken performance can be seen. [6] state that the conversion of rations is defined as the amount of ration spent to produce every kilogram of weight gain. The small ration conversion rate means that the number of rations used to produce one kilogram of meat is less, the higher the ration conversion means more financially wasteful.

\section{e. Percentage of Carcass}

Slaughter age showed a very significant effect $(\mathrm{P}>0.01)$ on the percentage of chicken carcasses, but the level of gamal leaf administration did not show a significant effect $(\mathrm{P}<0.05)$ as in tables 3 and 4. According to Hayse and Marion (1973) in [24], carcass weight produced is influenced by several factors, namely: age, sex, weight, body size and conformation, fatty, quality and quantity of rations, and strains maintained. Achieving carcass weights is closely related to weight loss and body weight gain [25].

The percentage of carcass is a comparison between carcass weight and cutting weight multiplied by $100 \%$. [22] states that the carcass component is relatively the same and is proportional to the body weight gain which will produce a carcass percentage that is not 
different.[16] added, the percentage of carcasses of 6 weeks old broiler chickens was in the range of $65-75 \%$. Factors that influence the percentage of carcass are nation, sex, age, feed, physical condition and abdominal fat [26]. This is because the ration containing gamal contains coumarin and tannin which can reduce the consumption of rations in chickens. This is consistent with the opinion of [27] that the presence of tannin can cause a decrease in the level of feed consumption and growth rate in broilers because tannins in the digestive tract have the ability to bind proteins. [25] states that carcass weight is closely related to cutting weight and body weight gain, the higher the weight of the slaughter, the higher the carcass weight and vice versa. One of the factors that influence carcass weight is the nutritional content of the ration. The part of the ration that plays a major role in carcass formation is the protein content. This means that the longer the maintenance period, the level of efficiency of feed use will decrease.

One of the nutrients that is very influential in carcass formation is protein. The protein content in the diet is needed for tissue growth. The amount of protein in the diet greatly influences the achievement of animal body weight, as stated in [28] one of the food substances that greatly influences the growth of carcass-forming tissue is protein. The percentage of chicken carcass is obtained from carcass data without feathers, head of neck, legs and contents of internal organs. The determinant carcass in super chicken carcass production is related to body weight. Chicken carcasses vary according to body size, obesity and chest level. The percentage of carcass data from the research results can be seen in Tables 3 and 4. As stated by [4] the percentage of carcass is the ratio between carcass weight and life weight multiplied by one hundred percent. According to [29] the percentage of carcass is influenced by the weight of the digestive tract, body weight, and genetics. Increasing the live weight of chickens will increase carcass weight and the percentage of carcass will increase and vice versa.

\section{Conclusion}

Based on the results and discussion can be concluded as follows:

a. There was a significant interaction $(\mathrm{P}<0.05)$ between the levels of fermented gamal leaves and cut age for variables of weight gain and feed consumption. Final weight variable and FCR, each factor shows a significant effect, but there is no interaction between the two $(\mathrm{P}>$ $0.05)$. For the percentage of carcass, the cutting age had a significant effect $(P<0.05)$, but the administration of fermented gamal leaf flour did not show a significant effect and there was no interaction between the two factors $(\mathrm{P}>0.05)$.

b. Giving fermented gamal leaves to level R1 (3\%) can significantly increase the growth of super chicken. The right cut can be done after the chicken is 10 weeks old (U2).

\section{References}

[1] Iskandar S, Mengenal Plasma Nuftah Ayam Indonesia dan Pemanfaatannya. Bogor: Balai Penelitian Ternak, 2010.

[2] B. Gohl, "Tropical Feed Information Summeries and Nutritive Value, Animal Production and 
Health," no. Series No. 12. FAO, 1981.

[3] S. P. A. Hardjosubroto,W, "Performans dari Ayam kampung dan Ayam Kedu. Makalah pada Seminar Pertama Tentang Ilmu dan Industri Perunggasan. Pusat Penelitian dan Pengembangan Peternakan, Bogor," 1977.

[4] A. . Nataamijaya, "Produktivitas Ayam Buras Di Kandang Litter pada Berbagai Imbangan Kalori Protein. Prosiding Nasional Seminar Peternakan dan Forum Peternak Unggas dan Aneka Ternak II. Balai Penelitian Ternak, Bogor," 1995.

[5] R. G. dan J. R. T. Steel, Prinsip dan Prosedur Statistika. Jakarta: PT Gramedia Pustaka Utama, 1991.

[6] Abrianto P, "Cara Mengolah Gamal untuk Pakan Ternak Sapi. http://www.duniasapi.com,” 2011.

[7] D. Z. Gunawan, Komposisi Zat Nutrisi dan Antinutrisi Beberapa Jenis Sorgum Sebagai Faktor Utama dalam Penyusunan Ransum Ternak. Risalah Simposium Prospek Tanaman Sorgum untuk Pengembangan Agroindustri. Balai Penelitian Tanaman Kacang-Kacangan dan Umbi-umbian. Bogor. 1995.

[8] M. D. . Wiradisastra, "Evektivitas Keseimbangan Energi dan Asam Amino dan Efisiensi Absorpsi dalam Menentukan Persyaratan Kecepatan Tumbuh Ayam Broiler. Disertasi. Institut Pertanian Bogor.," 1986.

[9] S. Sulastri, "Pengaruh Tingkat Pemberian Tepung Daun Gamal dalam Ransum Terhadap Komponen Tubuh dan Karkas Ayam Pedaging. Karya Ilmiah. Fakultas Pternakan. Institu Pertanian Bogor," 1984.

[10] Ichwan M. W, Membuat Pakan Ayam Ras Pedaging. Jakarta: PT. Agromedia Pustaka, 2003.

[11] R. Anggorodi, Ilmu Makanan Ternak Umum. Jakarta: PT Gramedia Pustaka Utama, 1980.

[12] A. Cabbas, "Tannings. www.cornelluniversity.edu/Cornellpoisonplant/Toxicagents/ Tannin/html (2 april 2008)," 2008.

[13] G. W. O. and T. Ambula, M.K., "Effect Of Shourgum Tannins, A Tannin Binder (Polyvinylpyrralidone) And Sotghum Inclusion Level On The Performance Of Broiler Chick,” Asian Aus. J. Anim Sci, vol. 14, no. 9, pp. 1276 - 1281, 2001.

[14] W. Widodo, "Nutrisi dan Pakan Unggas Konseptual. Departemen Pendidikan Nasional, Jakarta," 2002.

[15] M. R. dan A. D. Mathius, W., "Daya Konsumsi dan Daya Cerna Domba Terhadap Daun Gliricidia. Lembaran LPP. No 2-4 Tahun IX; 21-24, Bogor," 1981.

[16] S. Sutikno, I., "Coumarin dalam Daun Glirisidia. Ilmu dan Peternakan. Vol. 8(2). pp. 44-48," 1985.

[17] E. Tangendjaja, B, Wina, "Potential and Nutritional Value Of Leaf Meal From Fast Growing Tress. Procedings Feed Technology Workshop (Tan, R K H and Tangendjaja, B eds) Pp 48 - 68," 1993.

[18] A. . Sinurat, "Penggunaan Bahan Pakal Lokal dalam Pembuatan Ransum Ayam Buras," Wartazoa, vol. 9, no. 1, pp. 12-20, 2000.

[19] W. Widodo, "Tanaman Beracun dalam Kehidupan Ternak. Universitas Muhammadiyah, Malang," 2005.

[20] J. Wahju, Ilmu Nutrisi Unggas. Yogyakarta: UGM Press, 2005.

[21] and R. J. Y. Scott, M. L., M. C. Neisheim, Nutrition of Chickens (Thirth Ed.) M. L. Scott and Associates. New York: Ithaca, 1982.

[22] I. Sofjan, “Ayam Kampung Unggul. Badan Penelitian dan Pengembangan Pertanian, Jakarta,” 2012.

[23] M. Rasyaf, Manajemen Peternakan Ayam Broiler. Jakarta: Penebar Swadaya, 2005.

[24] H. Resnawati, "Bobot Potong Karkas dan Lemak Abdomen Ayam Ras Pedaging yang Diberi Ransum Mengandung Tepung Cacing Tanah (Lumbricus rubellus). Balai Penelitian Ternak, Bogor,” 2004.

[25] U. Haroen, "Respon Ayam Broiler yang Diberi Tepung Daun Sengon (Albizzia falcataria) dalam Ransum Terhadap Pertumbuhan dan Hasil Karkas,” J. Ilm. Ilmu-ilmu Peternak., vol. 6, no. 1, pp. 3441, 2003.

[26] K. A. Z. Subeki K., H. Abbas., "Kualitas Karkas (Berat karkas, Persentase Karkas dan Lemak Abdomen) Ayam Broiler yang diberi Kombinasi CPO (Crude Palm Oil) dan Vitamin C (Ascorbic 
Acid) dalam Ransum Sebagai Anti Stres. Jurnal Peternakan Indonesia. Vol.14(3). pp. 447-453," 2012.

[27] A. E. P. W. dan R. S. Rahayu, B. W. I., "Penampilan Pertumbuhan Ayam Persilangan Kampung dan Bangkok,” J. Ilmu Pengetah., vol. 5, no. 2, pp. 77 - 81, 2010.

[28] Soeparno, Ilmu dan Teknologi Daging. Yogyakarta: UGM Press, 2015.

[29] M. Rasyaf, Pengolahan Peternakan Unggas Pedaging. Kanisius. Yogyakarta. Yogyakarta: Kanisius, 1992. 